\title{
Country selection and aid allocation: A case of the Czech Republic
}

\author{
Gabriela Dufková ${ }^{*}$ \\ ${ }^{1}$ University of Economics in Prague, Faculty of International Relations, Department of World \\ Economy, nám. Winstona Churchila 1938/4, 13067 Praha 3 - Žižkov, Czech Republic
}

\begin{abstract}
Research background: Donors provide development aid from various reasons: while some of them might give aid based on the recipient's needs, some countries pursue their own agendas with their development programmes. Visegrad Group countries are mostly considered as egoistic donors that try to support security in the East European region and promote their trade.

Purpose of the article: This article draws back on the existing literature that focused on the motives behind the Czech development aid and examines influence of both egoistic and altruistic variables to determine which of these variables are important for the selection of countries to the aid portfolio and the allocation of aid funds. The researched variables are: number of asylum seekers, debt to the Czech Republic, Czech exports, unemployment in the developing countries, political and civil rights, and enrolment to the secondary education.

Methods: Probit-tobit analysis and a generalized linear model are employed in this paper.

Findings \& Value added: The results suggest that egoistic economic motives (debt and Czech exports) are important factors for both country selection and aid allocation, while the number of asylum seekers affects only the aid allocation. As per the altruistic reasons, the country selection depends on the unemployment rates, political and civil rights and the enrolment to secondary education. The aid allocation depends also on the unemployment rates, political and civil rights, and the ratio of girls enrolled to the secondary education.
\end{abstract}

Keywords: aid allocation; territorial selection; probit; tobit; generalized linear model

JEL Classification: F35; F50; O10

*Corresponding author: $\underline{x d u f g 00 @ v s e . c z}$ 


\section{Introduction}

Development aid has been historically provided from various motives. Ideally, the motives should be altruistic, that is, for example to improve the conditions in the developing countries, reduce poverty or increase human development. However, in reality, donors provide aid with their own egoistic motives, such as to strengthen economic and political ties in the developing world, promote their security and power interests or to improve their export capacities (SzentIványi, 2012; Nowak-Lehmann et al., 2009; Otor, 2014).

The Czech Republic is an emerging donor whose motives might differ from the traditional donor countries. As mentioned by Szent-Iványi (2012), the Visegrad Group countries (including the Czech Republic) never had any colonies, nor any interests in the Third World, nor any independent development strategies. Their societies are also not actively interested in the development topic and the governments, unlike traditional donors, must therefore duly justify any funds dedicated for aid.

There are many motives behind the development programmes and literature divides them generally into various groups. Firstly, there are official and unofficial motives (Opršal and Krylová, 2010). Official motives are declared in donor's strategies and policies; however, they might be not as influential as the unofficial motives hidden between the lines. Secondly, there are egoistic and altruistic motives (Szent-Iványi, 2012; Opršal and Harmáček, 2019). Egoistic motives represent donor's interests in the Third World, such as political influence or trade, while the altruistic motives include needs of the developing countries, such as hunger, literacy, infant mortality etc.

Based on these motives, donor countries can be divided to egoistic and altruistic donors as well. The United States, Japan, Italy or China are typically considered as egoistic donors, whereas the Scandinavian countries, Switzerland, and the Netherlands are found to be altruistic donors (Szent-Iványi, 2012; Liu and Tang, 2017; Berthélemy, 2006). As for the Visegrad countries, these are mostly regarded as egoistic donors by the literature (Kugiel, 2012; Szent-Iványi, 2012) as they use their development programmes to support safety and stability (Kugiel, 2012), and/or promote their economic interests (Opršal and Krylová, 2010).

The egoistic reasons behind the Visegrad programmes may be also observed in the portfolio of supported countries: the main focus is on close East European countries where the V4 states hold their own interests (Jankowski, 2018; Opršal et al., 2020) because any instability in this region would result in increased migration to the Visegrad countries, decline of trade and investment, and increase of organised crime (Szent-Iványi, 2012). The least developed countries are, on the other hand, supported only to fulfil commitments to the international community and the development flows to these countries are inadequate to meet the set international goals (Kováŕová, 2021). However, as mentioned by Chiel (2018), after the migration and economic crisis this region has been gaining more attention from the Visegrad Group as well.

This paper focuses on the reasons behind the Czech aid and tries to confirm whether Czech aid is driven by egoistic motives, such as safety and economy, or altruistic motives arising from the recipient's' needs. This paper is structured as follows: first, the following chapter describes employed methods and collected data. The second chapter presents the results of the analysis in Tables and summarises the main findings in text as well. The final chapter then discusses the results.

\section{Methodology}

As mentioned, the aim this paper is to evaluate what factors play an important role for the Czech decision makers in the selection of countries to the aid portfolio and also in the allocation of aid resources. To answer these questions a hybrid two-step probit-tobit model 
is employed in line with the existing literature (Dreher et al., 2012, Dreher et al., 2015, Harrigan a Wang, 2011, Harmáček et al., 2017, Opršal et al., 2017) and a generalised linear model is added to confirm the findings as well. First, data are analysed with the probit method in order to confirm the territorial selection of countries and in the second step, tobit method and the generalised linear model are employed to evaluate the allocation of aid funds. In both steps, a hybrid model is used in which altruistic and egoistic factors are analysed together.

Panel data have been collected for 132 countries that received any aid from the Czech Republic in the researched period for 21 years (from 1998 till 2018). The dependent variable for probit analysis is a binomial variable showing whether a country was a recipient of Czech aid (value 1) or not (value 0 ). The dependent variable for tobit analysis and the generalised linear model is the amount of aid provided to a country each year. This variable is marked as CZODA in the analysis, the data were retrieved from the OECD database and are measured in the USD current prices.

The independent variables were selected to reflect the officially declared aid goals of the Czech Republic as described in the Strategy of Foreign Development Aid for 2018 - 2030 (Ministry of Foreign Affairs, 2017). The variables are described in detail below with the respective goal indicated in brackets:

- The first variable reflecting the interests of the Czech Republic is the number of asylum seekers from the Third World countries in the Czech Republic (Czech goal: security and reduction of migration). This variable is marked as ASYL later in the analysis, the data were taken from the Czech Statistical Office and is measured as a number of people. Literature (Szent-Iványi, 2012, Horký, 2009) suggest that the prevention of illegal migration is an important motive behind the development programmes of all Visegrad countries, including the Czech Republic. It is expected that countries with a higher number of asylum seekers will have a higher probability of selection and also higher aid funds allocated by the Czech Republic.

- The second variable reflecting egoistic Czech interests is the debt of the Third World countries to the Czech Republic (Czech goal: tightening of economic ties). This variable is marked as DEBT later in the analysis, the information was obtained from the Ministry of Finance of the Czech Republic and it is measured in Czech Crowns. Few caveats need to be mentioned about the data. Firstly, the data were available only from 2005 onwards as the Ministry was responsible for this agenda only after this year. Secondly, some of the information is still considered confidential as some debt originated from purchase of military equipment and thirdly, the debt of former Yugoslavia (almost $600 \mathrm{~m}$ CZK in 2018) was still not officially accepted by the succession states. It is expected that this variable will have a positive impact on both selection and allocation as the Czech Republic can improve mutual relations with the debtor developing countries through aid, accelerate their economic growth and in the end also improve the chances of debt repayment.

- The last egoistic independent variable is the volume of Czech exports to the developing countries (Czech goal: tightening of economic ties). This variable is marked as CZEXP later in the analysis, the data were taken from the Comtrade database and are measured in USD current prices. The Czech Republic can help its exporters and promote their products through the development aid and it is expected based on the existing literature (Harmáček et al., 2017) that its influence on selection and aid allocation will be positive.

- The first altruistic independent variables connected to the needs of developing countries are the political and civil rights (Czech goal: Democratic Administration). These variables are marked as PR (political rights) and CR (civil rights), the data come from Freedom House statistics and are measured on a seven-point scale where one is the best score. Based on the existing literature (Harmáček et al., 2017), it is 
expected that the impact of this variable on both selection and aid allocation will be negative.

- The second altruistic independent variable is the unemployment rate in the Third World countries (Czech goal: economic transformation and growth). This variable is marked as UNEMP later in the analysis, the data were retrieved from the World Bank database and are measured as a percentage of unemployed workforce from the total workforce. It is expected that this variable will have a positive impact on both selection and aid allocation.

- The third altruistic variable is the share of students enrolled to the secondary education (Czech goal: inclusive and social development). This variable is marked as SENRL later in the analysis, the data come from the World Bank database and are measured as a percentage of students enrolled to the secondary education from the total potential student population. It is expected that this variable will have a negative impact on the selection and aid allocation meaning, the lower the share, the higher the probability of selection and the higher the aid resources allocated

- The last altruistic independent variable in this analysis is the share of girls enrolled in the secondary education (Czech goal: inclusive and social development). This variable is marked as FSENRL later in the analysis, the data come from the World Bank database and are measured as a percentage of girls enrolled to the secondary education from the total potential girl student population. Similarly, as above, this variable is also expected to have a negative impact on both country selection and aid allocation.

\section{Analysis}

First, all variables were tested for correlation and it was estimated that some of them are strongly correlated. Therefore, few models are tested in the analysis, always including noncorrelated variables. Model (1) includes variables DEBT, CZEXP, UNEMP and FSENRL. Model (2) includes only variables ASYL and SENRL as ASYL was strongly correlated with all other variables. Model (3) includes variables PR and UNEMP as PR was again strongly correlated with other variables and model (4) includes CR and UNEMP for the same reason.

Table 1 below summarises results of the probit analysis (selection of countries to the aid portfolio) and presents p-values for each variable and the estimation in brackets below. All results and their interpretations are valid only ceteris paribus.

Table 1. Selection of countries - probit analysis.

\begin{tabular}{|c|c|c|c|c|}
\hline variable & $\mathbf{( 1 )}$ & $\mathbf{( 2 )}$ & $\mathbf{( 3 )}$ & $\mathbf{( 4 )}$ \\
\hline Intercept & $\begin{array}{c}2.48 \mathrm{e}-05^{* * *} \\
(2.342 \mathrm{e}-01)\end{array}$ & $\begin{array}{c}0.114 \\
(0.0573319)\end{array}$ & $\begin{array}{c}0.000115^{* * *} \\
(-0.238812)\end{array}$ & $\begin{array}{c}3.23 \mathrm{e}-11 \text { *** } \\
(-0.513096)\end{array}$ \\
\hline ASYL & - & $\begin{array}{c}0.474 \\
(0.0001226)\end{array}$ & - & - \\
\hline DEBT & $\begin{array}{c}0.002082^{* *} \\
(3.212 \mathrm{e}-06)\end{array}$ & - & - & - \\
\hline CZEXP & $\begin{array}{c}0.000117^{* * *} \\
(1.122 \mathrm{e}-09)\end{array}$ & - & - & - \\
\hline UNEMP & $\begin{array}{c}0.001836^{* *} \\
(1.577 \mathrm{e}-02)\end{array}$ & - & $\begin{array}{c}0.000869^{* * *} \\
(0.012932)\end{array}$ & $\begin{array}{c}0.000243^{* * *} \\
(0.014293)\end{array}$ \\
\hline PR & - & - & $\begin{array}{c}7.54 \mathrm{e}-12^{* * *} \\
(0.082557)\end{array}$ & - \\
\hline CR & - & - & - & $\begin{array}{c}<2 \mathrm{e}-16^{* * *} \\
(0.145921)\end{array}$ \\
\hline
\end{tabular}




\begin{tabular}{|c|c|c|c|c|}
\hline SENRL & - & $\begin{array}{c}4.76 \mathrm{e}-08 * * * \\
(0.0034272)\end{array}$ & - & - \\
\hline FENRL & $\begin{array}{c}0.995199 \\
(-4.728 \mathrm{e}-06)\end{array}$ & - & - & - \\
\hline
\end{tabular}

Source: created by the author (2021)

Note: Regression coefficients are: ***significant at $1 \%$ level of significance; **significant at $5 \%$ level of significance; *significant at $10 \%$ level of significance.

The results suggest that the selection of developing countries to the Czech aid portfolio is positively influenced by egoistic economic variables DEBT (at 5\% level of significance) and CZEXP (at 1\% level of significance). The selection of countries is also positively influence by some altruistic variables, namely UNEMP (at 5\% level of significance), PR (at $1 \%$ level of significance), CR (at 1\% level of significance) and SENRL (at $1 \%$ level of significance).

On the contrary, the egoistic variable ASYL was not proved statistically significant for the country selection. As for altruistic reasons, variable SENRL was not tested as statistically significant either.

Table 2 below summarises results of the generalised linear model analysis (allocation of aid funds) and presents p-values for each variable and the estimation in brackets below. All results and their interpretations are valid only ceteris paribus.

Table 2. Allocation of aid funds - generalised linear model.

\begin{tabular}{|c|c|c|c|c|}
\hline variable & (1) & (2) & (3) & (4) \\
\hline Intercept & $\begin{array}{l}7.49 \mathrm{e}-05 * * * \\
(2.660 \mathrm{e}-01) \\
\end{array}$ & $\begin{array}{l}1.44 \mathrm{e}-12 * * * \\
(0.3206442)\end{array}$ & $\begin{array}{c}0.147857 \\
(-0.109391) \\
\end{array}$ & $\begin{array}{c}2.80 \mathrm{e}-05 * * * \\
(-0.38899) \\
\end{array}$ \\
\hline ASYL & - & $\begin{array}{c}0.0019 * * \\
(0.0006164) \\
\end{array}$ & 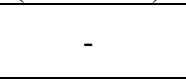 & - \\
\hline DEBT & $\begin{array}{c}0.0454^{*} \\
(1.114 \mathrm{e}-07)\end{array}$ & - & - & - \\
\hline CZEXP & $\begin{array}{l}2.38 \mathrm{e}-06 * * * \\
(8.729 \mathrm{e}-10)\end{array}$ & - & - & - \\
\hline UNEMP & $\begin{array}{l}1.50 \mathrm{e}-06^{* * *} \\
(2.812 \mathrm{e}-02)\end{array}$ & - & $\begin{array}{c}0.000396^{* * *} \\
(0.016564)\end{array}$ & $\begin{array}{c}0.000123^{* * * *} \\
(0.01788)\end{array}$ \\
\hline PR & - & - & $\begin{array}{l}1.6 \mathrm{e}-07^{* * * *} \\
(0.076860)\end{array}$ & - \\
\hline $\mathrm{CR}$ & - & - & - & $\begin{array}{c}2.14 \mathrm{e}-13 * * * \\
(0.14139)\end{array}$ \\
\hline SENRL & - & $\begin{array}{c}0.5238 \\
(0.0004922) \\
\end{array}$ & - & - \\
\hline FENRL & $\begin{array}{c}0.0158^{*} \\
(-2.229 \mathrm{e}-03)\end{array}$ & - & - & - \\
\hline
\end{tabular}

Source: created by the author (2021)

Note: Regression coefficients are: $* * *$ significant at $1 \%$ level of significance; $* *$ significant at $5 \%$ level of significance; *significant at $10 \%$ level of significance.

As the results indicate, the allocation of aid funds is positively influenced by all egoistic variables: ASYL (at 5\% level of significance), DEBT (at 10\% level of significance) and CZEXP (at 1\% level of significance). As per the altruistic variables, the results suggest that almost all of them influence the aid fund allocation: UNEMP (at $1 \%$ level of significance), PR and CR (at 1\% level of significance), and FENRL (at 10\% of significance). According to the generalised linear model, the only variable that does not affect the aid allocation is SENRL. 
Table 3 below summarises results of the tobit analysis (allocation of aid funds) and presents $\mathrm{p}$-values for each variable and the estimation in brackets below. All results and their interpretations are valid only ceteris paribus.

Table 3. Allocation of aid funds - tobit analysis.

\begin{tabular}{|c|c|c|c|c|}
\hline variable & (1) & (2) & (3) & (4) \\
\hline Intercept & $\begin{array}{l}2.99 \mathrm{e}-06^{* * *} \\
(-4.336 \mathrm{e}-01)\end{array}$ & $\begin{array}{r}<2 \mathrm{e}-16^{* * * *} \\
(-0.6186509) \\
\end{array}$ & $\begin{array}{l}<2 \mathrm{e}-16 * * * \\
(-1.439935)\end{array}$ & $\begin{array}{l}<2 \mathrm{e}-16^{* * *} \\
(-2.079679) \\
\end{array}$ \\
\hline ASYL & - & $\begin{array}{c}0.00270 * * \\
(0.0008827) \\
\end{array}$ & - & - \\
\hline DEBT & $\begin{array}{l}0.000549 * * * \\
(2.430 \mathrm{e}-07)\end{array}$ & - & - & - \\
\hline CZEXP & $\begin{array}{l}5.33 \mathrm{e}-09^{* * *} \\
(1.383 \mathrm{e}-09)\end{array}$ & - & - & - \\
\hline UNEMP & $\begin{array}{l}1.52 \mathrm{e}-08^{* * *} \\
(4.414 \mathrm{e}-02)\end{array}$ & - & $\begin{array}{l}\text { 7.11e-06*** } \\
(0.031952)\end{array}$ & $\begin{array}{c}5.34 \mathrm{e}-07 * * * \\
(0.035485)\end{array}$ \\
\hline PR & - & - & $\begin{array}{c}2.22 \mathrm{e}-14 * * * \\
(0.174278)\end{array}$ & - \\
\hline $\mathrm{CR}$ & - & - & - & $\begin{array}{c}<2 \mathrm{e}-16^{* * * *} \\
(0.319386)\end{array}$ \\
\hline SENRL & - & $\begin{array}{c}0.00193 * * \\
(0.0036360)\end{array}$ & - & - \\
\hline FENRL & $\begin{array}{c}0.049179 * \\
(-2.452 \mathrm{e}-03) \\
\end{array}$ & - & - & - \\
\hline Log (scale) & $\begin{array}{l}<2 \mathrm{e}-16^{* * * *} \\
(6.898 \mathrm{e}-01)\end{array}$ & $\begin{array}{c}<2 \mathrm{e}-16^{* * * *} \\
(0.7710107) \\
\end{array}$ & $\begin{array}{l}<2 \mathrm{e}-16^{* * *} \\
(0.755426)\end{array}$ & $\begin{array}{l}<2 \mathrm{e}-16^{* * *} \\
(0.745371)\end{array}$ \\
\hline
\end{tabular}

Source: created by the author (2021)

Note: Regression coefficients are: ***significant at $1 \%$ level of significance; ** significant at $5 \%$ level of significance; *significant at $10 \%$ level of significance.

The results of the tobit analysis mostly confirm the findings of the generalised linear model. All researched egoistic variables affect the aid allocation, ASYL (at 5\% level of significance), DEBT (at 1\% level of significance) and CZEXP (at 1\% level of significance). Also, all altruistic variables influence the aid allocation: UNEMP (at 1\% level of significance), PR and CR (at 1\% level of significance), SENRL (at 5\% level of significance), and FENRL (at $10 \%$ level of significance).

\section{Discussion}

The findings presented in the previous chapter suggest that both the selection of developing countries to the Czech development aid portfolio and the allocation of aid funds are driven by egoistic economic motives. This confirms the findings of the existing literature (Opršal and Krylová, 2010; Harmáček et al., 2017) that decision makers take into account the interest of the Czech economy and the exporters while setting up the framework of Czech development aid. Surprisingly, the motive of safety and prevention of migration did not prove statistically significant for the country selection suggesting that Czech economic interests play much bigger role that safety.

All egoistic motives were, however, statistically significant for the fund allocation meaning that if a country was already selected as a receiver of Czech aid, the volume of aid it received was influenced by Czech economic and safety interests. 
The decisions on country selection and aid allocation are also influenced by altruistic reasons. The country selection depends on the unemployment rates, political and civil rights and the enrolment to secondary education. The aid allocation depends also on the unemployment rates, political and civil right, and also on the ratio of girls enrolled in the secondary education, while the significance of enrolment of all students to secondary education stays unclear and depends on the model selected.

Based on the results it may seem that both egoistic and altruistic motives are considered during the decision-making process, however, it must be noted that the altruistic motives might be often interconnected with the egoistic ones: a high unemployment in a Third World country or difficult political situation there might result in increased migration and decreased trade. By fighting these inner issues in the developing countries, the Czech Republic might thus pursue its own goals to support security and trade in the region as well.

\section{Conclusion}

This paper focused on the selection of the partners of the Czech development aid from the developing countries and the aid allocation to them. First, donor's motives were discussed, which can be divided into two main categories: (1) official and unofficial, and (2) altruistic and egoistic. The Czech Republic is an emerging donor and its motives are generally seen as egoistic.

With the use of a hybrid two-step probit-tobit model, an analysis was conducted to answer the following two research questions: What factors influence the selection of developing countries in case of the Czech Republic? And what factors influence the aid volumes provided to these countries from the official Czech development aid funds? Based on the collected panel data consisting of 132 countries that received any aid from the Czech Republic and a 21-year-long period (from 1998 till 2018), it has been concluded that the selection of developing countries is positively influenced the debt of the country to the Czech Republic, Czech exports, unemployment rate in the developing countries, political and civil rights and last but not least by the enrolment levels to the secondary education. The allocation of aid funds is then influenced by the number of asylum seekers from the given country in the Czech Republic, the debt of the country to the Czech Republic, Czech exports, unemployment rate in the developing countries, political and civil rights and finally by the enrolment levels of girls and in general to the secondary education.

The analysis has shown that although the Czech Republic is generally considered as an egoistic donor, its decision makers do take into account also some altruistic reasons while setting the up the aid development partnerships and while distributing the aid funds.

\section{Acknowledgements}

This work was supported by an IGA project called "Case studies in developing countries comparison of attitudes in natural resource management and project management of development aid", no. 6/2020 registered at University of Economics and Business.

\section{References}

1. Chmiel, O. (2018). The engagement of Visegrad countries in EU-Africa relations. Discussion Paper.

2. Dreher, A., Nunnenkamp, P., \& Schmaljohann, M. (2015). The allocation of German aid: Self-interest and government ideology. Economics and Politics, 27(1), 160-184. 
3. Dreher, A., Nunnenkamp, P., Öhler, H., \& Weisser, J. (2012). Financial dependence and aid allocation by swiss NGOs: A panel tobit analysis. Economic Development and Cultural Change, 60(4), 829-867.

4. Harmáček, J., Syrovátka, M., \& Opršal, Z. (2017). Factors of Czech aid selection and allocation: Panel probit and tobit analysis. Politicka Ekonomie, 65, 179-197.

5. Harrigan, J., \& Wang, C. (2011). A new approach to the allocation of aid among developing countries: Is the usa different from the rest? World Development, 39(8), 1281-1293.

6. Horký, O. (2009). Rozvojový rozměr české zahraniční politiky: Nástroj zahraniční politiky nebo snižování globální chudoby? In Kořan M.(et al.) Česká zahraniční politika v roce 2008: Analýza ÚMV. Praha: Ústav mezinárodních vztahů

7. Jankowski, B. (2018). Changes in the European eevelopment policy after 2020. On-line journal modelling the new Europe, 26.

8. Jean-Claude, B. (2006). Bilateral donor's interest vs. recipients' development motives in aid allocation: Do all donors behave the same? universite paris1 Pantheon-Sorbonne (post-print and working papers) halshs-00305510, HAL.

9. Kovářová, E. (2021). Volume and territorial distribution of the Czech Republic's official development assistance flows to least developed countries. Review of Economic Perspectives, 21(1), 79-102.

10. Kugiel, P. (2012). The development cooperation policies of Visegrad countries - An unrealised potential. The Polish Quarterly of International Affairs, 21(4).

11. Liu, A., \& Tang, B. (2017). US and China Aid to Africa: Impact on the donor-recipient trade relations. MPRA Paper No. 82276. Accessible from: https://mpra.ub.unimuenchen.de/82276/.

12. Ministerstvo zahraničních věcí (2017). Strategie zahraniční rozvojové spolupráce České republiky na období 2018 - 2030.

13. Nowak-Lehmann, D. F., Martínez-Zarzoso, I., Klasen, S., \& Herzer, D. (2009). Aid and trade - A donor's perspective. The Journal of Development Studies, 45(7), 1184-1202.

14. Opršal, Z., \& Harmáček, J. (2019). Is foreign aid responsive to environmental needs and performance of developing countries? Case study of the Czech Republic. Sustainability, (11), 401.

15. Opršal, Z., Harmáček, J., \& Syrovátka, M. (2017). Geography of Czech aid: Where and why Czechia promotes development? Geografie, 122(2), 169-189.

16. Opršal, Z., \& Krylová, P. (2010) Territorial aspects of development assistance of the Visegrad countries. Sborník XXII Sjezdu Geografické společnosti Ostrava 2010, 812818.

17. Opršal, Z., Harmáček, J., Vítová, P., Syrovátka, M., \& Jarecka-Stępień, K. (2020). Polish and Czech foreign aid: A 'mélange' of geopolitical and developmental objectives. Journal of International Relations and Development, 24(2), 279-305.

18. Otor, S., A. (2014) Japan's official development assistance and exports to asian countries: The donor's perspective. Institutions and Economies, 6(3), 60-91.

19. Szent-Iványi, B. (2012). Aid allocation of the emerging Central and Eastern European donors. Journal of International Relations and Development, (15), 65-89. 